\title{
Mechanism Development for Corporate Income Taxation in Russia
}

\author{
Abdusalim M. Abdulgalimov ${ }^{1 *}$, Visradi V. Anasov ${ }^{1}$, Zina A. Arsakhanova ${ }^{1}$ and Ramazan A. Nabiev ${ }^{2}$ \\ ${ }^{1}$ Chechen State University, 32, str. A. Sheripova, Grozniy, Chechen Republic, 364000, Russian Federation; \\ abd16@yandex.ru,visradi@gmail.com,zina_ars@mail.ru \\ ${ }^{2}$ Astrakhan State Technical University, 16, str. Tatischeva, Astrakhan, 414056, \\ Russian Federation; Nabiev56@list.ru
}

\begin{abstract}
Objectives: The article substantiates the necessity of the development of corporate income taxation as a factor of the economic growth of regions. The purpose of the study is to establish an effective system of corporate income taxation, taking into account the specifics of the tax base in various regions. Methods/Statistical Analysis: In an effort to reach the above-mentioned goal, the methods of theoretical and empirical research were used. The authors applied a systematic approach to analyzing the methods of corporate income taxation, making it possible to identify the economically viable method of profit taxation. A unique feature in studying the methodology of taxation is the proposal of a differentiated approach to the application of corporate income taxation methods depending on the state of the tax base. Findings: As opposed to the proportional taxation method, introduced in the Russian business life, the proposed methods of progressive and differentiated application of the tax on profits rate for corporations make it possible to specify the actual tax rate corresponding to the economic climate in a region. Applications/Improvements: The key methods for income taxation related to companies in conditions of the developing economy have been identified. They can be used up to design a development strategy for the taxable base at the regional level. The proposed methods were identified as alternate solutions to the methodological problems in corporate income taxation.
\end{abstract}

Keywords: Corporate Income Tax, Fiscal Policy, Progressive Taxation Method, Proportional Taxation Method, Tax Rate Differentiation Method

\section{Introduction}

In the modern period, the establishment of the state tax system is of paramount importance for the development of society and economy. In this context, the tax system should become a factor in economic growth. The practice of the functioning of tax systems in different countries shows that the application of a tax system can lead to ambiguous results, which are sometimes undesirable from the perspective of the national economy. In order to receive desirable results, acceptable for both the state and taxpayers, it is necessary to establish a tax system that would provide for the balance of the interests. These categories include the property and the legal delimitation of the rights to use and dispose of property objects, a mandatory fee for services that economic entities render to each other, including public services, for which taxes are paid.

The practice shows that the regularities of the market economic system are not always observed. This obviously leads to the unbalanced development of society. In the case of the Russian tax system, this policy is virtually conducted from the very beginning of the introduction of the new tax system. This indicates that the prerequisites for a more harmonious combination of the interests of the state and taxpayers have not been created in our country. The state still remains the main distributor of financial resources in the country. However, in market conditions, organizations and individuals should earn resources to continue their business activities and existence by

${ }^{*}$ Author for correspondence 
themselves; if rapid economic growth is necessary, they may resort to the use of financial instruments offered by the market system itself, in particular, to the use of public support, raising bank loans.

The present article discusses the methodological problems existing in the Russian system of corporate income taxation and suggests possible solutions. The proposed methods of corporate income taxation do not contradict to theoretical perspectives existing in world economics and the fundamentals of Russian tax law, which makes it possible to conclude that their use is theoretically justified.

The effectiveness of the corporate income tax depends on the specifics of its application in different countries, which is determined by the political and economic objectives that the state sets for the society. Depending on this, the corporate income tax in different countries has a different value for the formation of the state budget. In the United States, Japan, and the United Kingdom, the corporate income tax occupies a leading place in the tax system $^{1}$, while in most countries of the EU a leading place is occupied by the VAT and personal income taxation? It should be noted that the corporate income tax is the most efficient under circumstances where more advanced accounting standards are applied $\stackrel{3}{*}$.

\section{Methodology}

\subsection{Theoretical Substantiation of Corporate Income Taxation}

Corporate income taxation is a scientifically well-founded subject. However, the problems of corporate income taxation are widely discussed. In accordance with the goal of the article, let us focus on the issues which are of great concern to legislators and practitioners in setting and applying the corporate income tax.

The analysis of the authors' conclusions on corporate income taxation makes it possible to assert that in practice the organizations not involved in the formation of public goods can use them quite legitimately ${ }^{4}$. For example, Atkinson and Stiglitz in their lectures on the economic theory of the public sector indicate that any companies, regardless of the level of their participation in creating the public infrastructure, use the services of public institutions in equal measure ${ }^{5}$. The same opinion is shared by the authors of the European Tax Handbook. It states that taxpayers, by developing the public sector, ensure the economic basis of the state institutions because the latter require certain expenses from the society. The practice shows that when some organization does not participate in these expenses, it can still enjoy the benefits created by the state institutions to the full extent ${ }^{-}$.

The literature provides the evidence that the size of the real sector of the economy depends on the effective corporate tax rate. This means that the corporate tax affects the business activity. It was also found that it influences the distribution of financial resources between production and non-production sectors of the economy ${ }^{7}$. In this regard, it should be taken into account that there can be no equivalent between the payable income (profit) tax and the cost of services received by a certain taxpayer from the state. But if tax relations are based on the equivalent of the payable taxes to the received services, they assume the quality of exchange relations. The latter, undoubtedly, results in the fact that if public services do not correspond to the paid taxes, taxpayers acquire the right not to pay taxes.

Considering the methods applicable in the corporate income taxation, let us turn to the Tax Code of the Russian Federation. The corporate income tax rate is set to be equal to 20 per cent ${ }^{8}$. Applying a certain method as an element of the taxation mechanism is of fundamental importance both for establishing an effective tax system. In this regard, Professor Goncharenko writes that a correctly formed tax policy and a well-adjusted tax mechanism, taking into account the requirements for its construction and operation, are the necessary prerequisites of effective taxation ${ }^{9}$. Analyzing the taxation methods, McConnell and Brue, the authors of "Economics", relate the changes in the tax rates to the changes in the volume of the gross domestic product. They note: "the more progressive the tax system, the greater the economy's built-in stability" 10 .

Some researchers conclude that taxes are, "most likely, ineffective tools for initiating significal changes in the entrepreneurial activity” 11 . Many economists advocate expanding the tax base: "corporate tax base broadening is likely to yield smaller welfare gains than reforms that reduce the distortion between business and non-business capital or between current and future consumption" $\underline{12}$. The ultimate goal of the tax regulation is to ensure the balance of the interests of three actors: the state, economic entities and citizens ${ }^{13}$.

In this regard, it is necessary to conduct a study of the impact of this tax on the balance in the economy as a whole, instead of identifying its influence on the balance at the level of individual structural units $\mathrm{I}^{\underline{14}}$. Relieving the corporate tax 
burden is possible as a result of the minimization of administrative barriers. The legislators should clearly define the element base of taxes and their application procedure, in order to reduce the administrative burden for taxpayers ${ }^{15}$.

\subsection{Characteristics of the Corporate Income Taxation Methodology}

The purpose of this paragraph is to identify the content of the methods of applying the corporate income tax in the heterogeneous economic conditions and, on this basis, determine which method of corporate income taxation is most effective in certain conditions of economic development. In order to achieve the goal of the study, it is proposed to consider the following methods of corporate income taxation: proportional method of corporate income taxation; progressive method of corporate income taxation; method of differentiated application of the established corporate income tax rate, depending on the level of the economic development of a region as a subject of consolidated tax reporting to the state budget.

In the Russian Federation, the proportional method is applied for tax purposes. The method of differentiation of the legally established corporate income tax rate by regions, depending on the level of their economic development, is proposed by the authors and is for the first time used in this article for the analysis of the corporate taxation system existing in the Russian Federation.

The proportional method implies the equivalence of income taxation for all taxpayers. Identical organizations that operate in different economic conditions (e.g., physical deterioration and obsolescence of the industrial equipment at one enterprise are higher than at another one, the costs of training and retraining of personnel are different, etc.) receive different amount of profit; therefore, they don't have equal opportunities for economic development. These organizations after paying the same amount of income tax will have unequal financial opportunities for economic growth.

We should not forget that organizations with large income are generally medium-sized and large enterprises, which bear a greater social burden, as compared to organizations with low income which do not have financial capabilities for a broad social support of the population. This social support includes providing jobs and wages to a large number of citizens, making contributions to extra budgetary social funds, providing guarantees, related to medical treatment and recreation of the staff.
Furthermore, the possibilities for the participation of organizations with low income in creating the conditions for economic growth of a given society are lower than those of organizations with large income. However, the current economic conditions in the Russian Federation indicate that Russian organizations not always and not in every region participate in creating these conditions. At the same time, all organizations, regardless of the amount of their income, equally enjoy public benefits created by the state institutions.

Summing up the theoretical part of the article, it should be noted that the maximum efficiency of corporate income taxation can be achieved in case if not only legal, but also business, economic and social obligations of an organization are determined. In this situation, the amount of the paid tax is a function of not only fiscal (legal) obligation, but also business, economic and social obligations. In the mathematical language, it can be written in the form of the following formula:

$$
T=f(\mathbf{F}, \mathbf{B}, \mathbf{E}, \mathbf{s})
$$

where $\mathrm{T}$ - tax amount; the variable $(\mathrm{F})$ - the fiscal obligation of the organization; the variable (B) - business obligation of the organization; the variable $(\mathrm{E})$ - economic obligation of the organization; the variable (S) - social obligation of the organization.

If the corporate income tax is a function of many variables, it is possible to say that the proportional method of taxation which is applied in the Russian tax system does not take into account all socio-economic obligations of organizations to the society.

\section{Results}

\subsection{The Result of Applying the Proportional Method of Taxation}

Thus, the current situation in the corporate income taxation is associated to the proportional taxation method applied on the Russian tax system. The corporate income tax tends to decrease, which requires an integrated approach to solving the problem of increas-

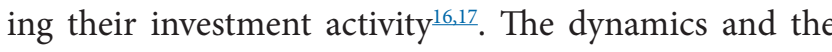
relative share of the corporate income tax in tax revenues of the consolidated budget of the Russian Federation in 2012-2014 are shown in Table 1.

The data of Figure 1 show that the return of the corporate income tax to the budget system of the country 
Table 1. Dynamics and the relative share of the corporate income tax in tax revenues to the consolidated budget of the Russian Federation

\begin{tabular}{|c|c|c|c|}
\hline \multirow{2}{*}{ Taxes } & \multicolumn{3}{|c|}{ Years } \\
\cline { 2 - 4 } & 2012 & 2013 & 2014 \\
\hline $\begin{array}{c}\text { Tax revenues to the consolidated } \\
\text { budget of the Russian Federation, } \\
\text { billion rubles }\end{array}$ & 17089.8 & 18202.5 & 19976.0 \\
\hline $\begin{array}{c}\text { Corporate income tax, billion } \\
\text { rubles }\end{array}$ & 2355.7 & 2071.9 & 2374.7 \\
\hline $\begin{array}{c}\text { Relative share of the corporate } \\
\text { income tax in the total amount } \\
\text { of the tax revenues to the } \\
\text { consolidated budget, } \%\end{array}$ & 13.7 & 11.4 & 11.8 \\
\hline
\end{tabular}

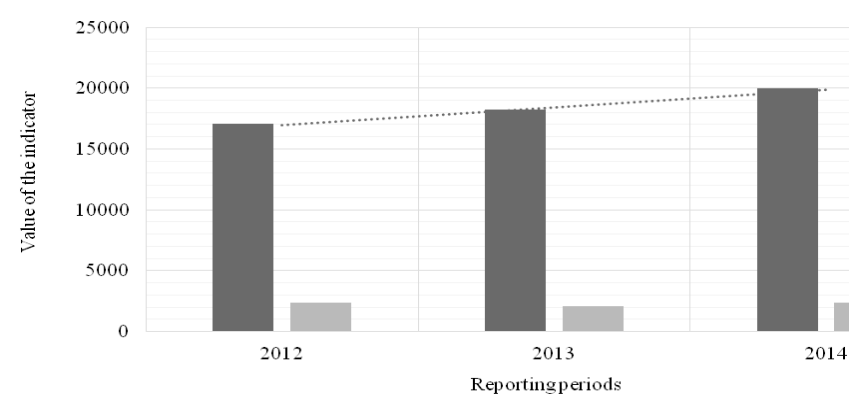

- Tax revenues to the consolidated budget of the Russian Federation, billion rubles nCorporate income tax, billion rubles

Figure 1. Dynamics of corporate income tax.

is not reduced. However, the relative share of the corporate income tax in the total amount of tax revenues declined by almost $2 \%$, as compared to 2012 . At the same time, the total amount of tax revenues to the consolidated budget demonstrates a stable growth trend.

The reduction in the tax base for corporate income tax indicates either reducing the financial capacity of existing organizations or a reduction in the number of companies themselves. In the Russian, both trends are observed. This is proved by the fact that the goods (services) produced by most Russian organizationsareuncompetitive as compared to their imported counterparts. For example, $91.96 \%$ of the exports from the Russian in 2015 were made up by oil, gas, non-renewable resources, agricultural products and wood, while the exports of processed goods made up only $8.04 \%^{\frac{18}{2}}$. Therefore, the demand for domestic goods and services is reducing, which results in a reduction of sales revenue, and, respectively, of the tax base, i.e. income. The reduction in profits, as is known, leads to a reduction in tax deductions. Besides, the price burden on consumers is growing, because the discretionary (after-tax) income reduces alongside with a reduction in the level of revenue and doesn't allow to fully and efficiently satisfy the needs for goods and services.

As the Russian practice shows, in this case the tax becomes a function of only one variable (fiscal). This is promoted by the current system of corporate income taxation, based on the policy, in which the public interests are prioritized.

Thus, the use of the proportional method of corporate income taxation does not ensure social justice and economic expediency under the current economic conditions in the Russian. The main reason is that in case of using the proportional method, in the context of weak economic development, organizations cannot ensure the financial capability for solving social problems of the staff and become an economic entity that actually shapes the conditions for economic growth.

\subsection{The Economic Necessity for Applying the Progressive Method of Corporate Income Taxation}

The efficiency of tax systems may be based on their progressiveness. In this case, progressiveness is understood as a taxation method, according to which tax rates rise with an increase of the amount of taxable income. The use of the progressive taxation method promotes the development of entrepreneurial activity ${ }^{19}$. The greatest effect of the manipulation of tax rates can be achieved through applying the progressive method of taxation. The progressive method of taxation, as opposed to the proportional method, ensures social fairness in tax relations, and provides more opportunities to observe the interests of both the state and taxpayers.

The policy of reducing tax rates and broad application of corporate income tax credits has been observed in developed market economies in the last decade. Reducing tax rates and the establishment of preferential tax policy are obviously affected by the budget concept of the state, which, in one way or another, sets the task of increasing the business activity ${ }^{20}$ and, consequently, increasing the tax base, while correlating it to relieving the tax burden. The experience shows that in countries, which pursue the fiscal policy aimed at reducing the tax burden on the manufacturer, the products are sold in the world market without any problems. Among such countries, there are Germany, the United States, France, and the United Kingdom. In the Russian Federation, the corporate 
income tax had its own path of development. However, despite the fact that economic conditions required the application of progressive corporate income taxation, the Russian tax authorities hesitated about shifting to this taxation method.

At the moment, this issue remains relevant, which requires switching to the progressive method of corporate income taxation. The progressive method of corporate income taxation, as opposed to the proportional method, ensures a socially fair distribution of the tax burden among taxpayers. The progressive method of corporate income taxation enables organizations to remain active economic agents. With the reduction (increase) in the tax base, the tax rate should also change. The progressive taxation method, as opposed to the proportional method, enables companies to retain a large portion of small income. In this regard, some scholars argue that this situation results in increasing the growth rate of the entrepreneurship ${ }^{21}$.

The progressive taxation method involves the rate scale, which should have clearly defined upper and lower limits. If these conditions do not ensure the resumption of production, the tax rate should be equal to zero, because otherwise, the organization will cease to be a socially active subject, providing the conditions for the economic growth in the society. The upper limit of the tax rate in case of corporate income taxation should be at the level of 30-33\% of the taxable base $\mathrm{e}^{22}$, because above this limit, the organization will cease to be an economically active subject, providing the conditions for economic growth. Besides, the global tax practice shows that effective tax rates are determined by finding the average effective tax rate equal to $30 \% \frac{23}{}$.

\subsection{The Method of Tax Rate Differentiation as a Way to Solve the Problem of Imbalance in the Country's Economy}

The method of differentiated application of legally established corporate income tax rates, depending on the level of economic development of a region as a subject of consolidated tax reporting to the state budget. This taxation method has good prospects of application in economies with an uneven level of regional development. In the Russian Federation, there are 85 regions. The highest value of the gross regional product per capita in 2014 was 4252.4 thousand rubles, while the lowest -45.8 thousand rubles, which is 92.8 times less ${ }^{24,25}$. Table 2 shows the data on the return of the corporate income tax by the federal districts of the Russian Federation.
The data in Table 2 show that during the studied year, in 30 regions of the country the tax base not only didn't expand, but even significantly decreased. This indicates that in case of using the proportional method of corporate income taxation, the tax regulation of the activities of the organizations doesn't take place at the regional level, despite the fact that $83 \%$ of corporate income tax is distributed to the regional budget. The way out of the current situation can imply either tightening the fiscal measures in relation to those organizations that do not expand the income tax base, or taking measures to encourage the activity of organizations expanding the tax base.

However, neither the first nor the second method can yield positive results in the context of the permanent dependence of a region on the subsidies from the federal budget ${ }^{26}$. There are several reasons, which include the following: 1) In the absence of adequate financial resources, the production activities of organizations are reduced, and the amount of tax revenue decreases, respectively, which causes the regions to attract subsidies; 2) The received subsidies; 3) The human resources of large and mediumsized organizations, which are payers of the corporate income tax; 4) In beneficiary regions, large and mediumsized enterprises stand idle or are closed down due to the physical deterioration and obsolescence of manufacturing equipment; 5) A part of corporate income tax amounting to $18-20 \%$ of the established rate of this tax, which is left by the federal center in beneficiary regions, will not be adequate for boosting the production and the financial restructuring of organizations, due to its insignificance. For the purpose of illustration, Figure 2 graphically shows the changes in the tax base.

Table 2 and Figure 2 show that there are entire federal districts, where the tax base virtually doesn't grow; on the contrary, it is reduced. Such districts include the North Caucasian Federal District, and a number of regions of the Ural and Far Eastern Federal Districts. As seen from Table 2 and the graph in Figure 2, the measures taken by the state fail to produce the required results in these regions. Therefore, it is necessary to fundamentally change the attitude of the leadership of organizations and the public authorities in the regions to the problem of the corporate income tax base and to the tax itself, which is the function of fiscal, economic, business, and social variables ${ }^{27}$.

The way out of the current situation, alongside with increasing the accountability of officials, may involve using the method of differentiating the established corporate income tax rate by regions, depending on the level of their 
Table 2. Dynamics of corporate income tax in the consolidated budget of the region in 2015 , in $\%$ to 2014 , by federal districts.

\begin{tabular}{|c|c|c|c|c|c|c|c|c|c|c|c|c|c|}
\hline \multirow[t]{2}{*}{ Federal districts } & \multicolumn{13}{|c|}{$\begin{array}{l}\text { The number of regions where a change in the amount of corporate income tax took } \\
\text { place, in } \% \text { (ranging from }-30 \text { to }+90)\end{array}$} \\
\hline & -30 & -20 & -10 & 0 & 10 & 20 & 30 & 40 & 50 & 60 & 70 & 80 & 90 \\
\hline Central Federal District & & & 4 & 1 & 4 & 5 & & 2 & & 1 & & & \\
\hline Northwestern Federal District & & & & 2 & & 6 & & & 1 & 1 & 1 & & \\
\hline Southern Federal District & & & & 2 & 2 & 1 & & 1 & & & & & \\
\hline North Caucasian Federal District & & & 1 & 5 & 1 & & & & & & & & \\
\hline Volga Federal District & & & 3 & 2 & 4 & 2 & & 1 & 2 & & & & \\
\hline Ural Federal District & 1 & 2 & & & & & & 1 & & & & 1 & 1 \\
\hline Siberian Federal District & & & 1 & 3 & 2 & 1 & 1 & 2 & 1 & 1 & & & \\
\hline Far Eastern Federal District & & 1 & & 2 & 2 & 1 & & 1 & 1 & & & & 1 \\
\hline Total number of regions & 1 & 3 & 9 & 17 & 15 & 16 & 1 & 8 & 5 & 3 & 1 & 1 & 2 \\
\hline
\end{tabular}

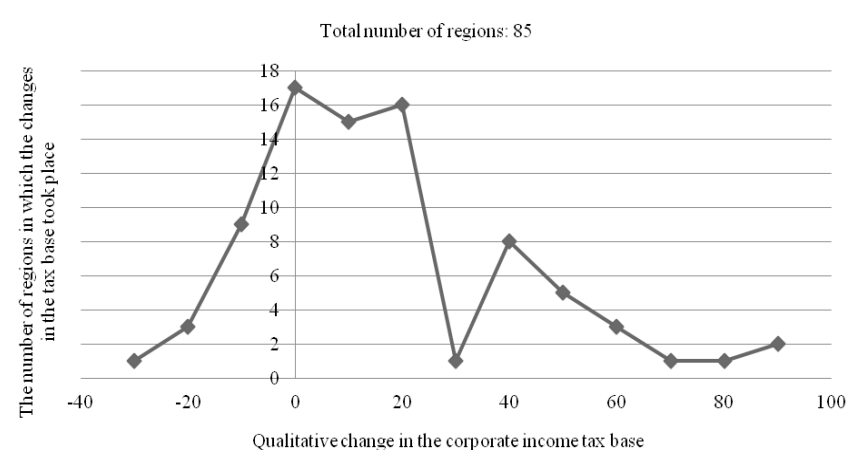

Figure 2. Changes in the corporate income tax base by regions of the Russian Federation in 2014.

economic development as subjects of consolidated tax reporting to the state budget. If a region does not have the material and financial resources for expanding the tax base, it may be exempted from the corporate income tax until it creates this tax base. Therefore, the range of tax rates for different regions may vary from $0 \%$ to $20 \%$. The upper limit should correspond to the tax rate, established in the country, i.e. $20 \%$. The duration of these measures should also be specified by the law, for their compulsory execution.

\section{Discussion}

The system of corporate income taxation is only effective in case of observing the market regularities in the society under consideration. For example, the state should not interfere in the mechanism of the distribution of financial resources at all stages of capital circulation. This condition is fulfilled in case if the state clearly defines the role and place of taxes in this mechanism.
For corporate income taxation in the Russian, the proportional method is applied, which supposedly complies with the principle of the uniformity of taxation; however, its application obviously violates the rights of taxpayers related to the fairness of tax relations. This is substantiated by the fact that in case of using the proportional method of taxation the tax burden on organizations grows. To solve this methodological problem, it is proposed to apply the progressive method of taxation, which ensures a uniform distribution of the tax burden on organizations with varying levels of profitability.

The practical application of the proposed method of tax rate differentiation by regions may proceed as follows. The uniform corporate income tax rate, established by the state, remains unchanged (20\%). This rate is considered as the upper limit in case of its correlation. Depending on the development of a region, the tax rate can be reduced.

Applying the progressive and differential methods of corporate income taxation enables taxpayers to conduct active business operations. In this case, the basic theoretical principles of the functioning of taxes are not violated, and all the tried and tested legal rules of taxation are observed. The application of the progressive taxation method is implemented by using the scale of rates, in which the basic rate should be determined as the national average. The lower limit of the rate should be determined depending on the industrial programs, the implementation of which requires more financial expenses as compared to the production. The determination of the upper limit of the tax rates within the scale should be based on the theoretical justification available in the economic literature, that is, it should not exceed $33 \%$ of the taxable income. 


\section{Conclusion}

The proportional method of corporate income taxation, despite the apparent uniformity, does not ensure the social fairness of taxation. The proportional method does not provide for the uniformity of distribution of the tax burden on taxpayers; therefore, the use of this method in corporate income taxation deepens the existing unevenness in the economic development of regions. The ineffectiveness of the proportional method in the context of the Russian economy has been aggravated by the failure to regard the tax as an economic category. The tax is seen as a function from only one fiscal indicator, and not as a function of fiscal, business, economic and social indicators of the development of society, as suggested in the methodological part of the present article.

It was proved that the tax as an economic category is implemented in an environment which ensures the uniformity of the tax burden distribution. It was found that the tax as an economic category is implemented in case of applying the progressive taxation method, as in this case the uniformity of the tax burden distribution is ensured. The progressive method of corporate income taxation is proposed as a measure taken by the government to reform the system of corporate income taxation.

An essential factor in the development of the system of corporate income taxation is the correlation of the tax rate to the general level of economic development of a certain region. This statement is relevant in the context of the Russian economy, where an obvious imbalance in the levels of the economic development of regions is observed. To eliminate the financial dependence of regions on the federal center, the state should develop a fiscal policy providing for the correlation between the taxation level and the degree of economic development, not only at the country level, but also at the regional level. In this regard, it is proposed to use the method of differentiated application of the established corporate income tax rate, depending on the level of the economic development of a region. The proposed measures of improving the system of taxation make it possible to: determine the real place of the tax as an economic category; identify the value of the corporate income tax as a factor of economic growth.

\section{References}

1. Antonova OV. Tax systems of foreign countries: study guide. Khabarovsk: Editorial and Publishing Center of the Khabarovsk State Academy of Economics and Law. 2010; p. 28.

2. Tolstopyatenko GP. Moscow: MGIMO: European tax law (problems of theory and practice) [dissertation]. 2001; p. $148-51$.

3. Rin DM, Giacomo DM, Sembenelli A. Entrepreneurship, firm entry, and the taxation of corporate income: evidence from European Journal of Public Econmics. 2011 Oct; 95(9-10):1048-66.

4. Kuzmin EA, Semyonovykh SM. Rethinking of Coase theorem: externalities and uncertainty. IJEFI. 2015 Oct; 5(4):875-83.

5. Atkinson A, Stiglitz J. New York: McGraw-Hill: Lectures on public economics. 1980.

6. Kesti J, editor. Amsterdam: IBFD Publications BV: European tax handbook. 2002.

7. Djankov S, Ganser T, Liesh MC, Ramalho R, Shleifer A. The effect of corporate taxes on investment and entrepreneurship. American Economics and Journal of Macroecon. 2010 Jul; 2(3):31-64.

8. Tax Code of the Russian Federation 2000. Article 284: tax rates. Date accessed: 2000: Available from: http://base. garant.ru/10900200/.

9. Goncharenko LV. Taxes and tax system of the Russian Federation: textbook of Moscow: Yurayt. 2010; p. 544.

10. McConnell CR, Brue SL. Economics. Part 2: national income, employment and fiscal policy. Date accessed: 2016: Available from: http://www.be5.biz/ekonomika/e016/toc.htm.

11. Bruce D, Mohsin M. Tax policy and entrepreneurship: new time series evidence. Small Business and Economics. 2006 Jun; 26(5):409-25.

12. Viard AD. Two cheers for corporate tax base broadening. National Tax Association 2009 Sep; 62(3):399-412.

13. Mayburova IA. Tax policy. Theory and practice: a textbook of Moscow: Unity-Dana. 2014; p. 518.

14. Harberger A. The incidence data of the corporate tax. Journal of Political Economics. 1962 Jun; 70:215-40.

15. Hubbard RG. Corporate tax integration: a view from the treasury department. The Journal of Economic Perspectives. 1993; 7(1):115-32.

16. Abdulgalimov AM, Dzhardisov DKH. Tax privileges and stimulation of business in Russia and foreign countries. Modern problems of science and education. 2015 Jun; 2(3):6.

17. Dynamics of the return of taxes, duties and other obligatory payments to the consolidated budget of the Russian Federation [Internet]. Federal State Statistics Service. htmDate accessed: 2015: Available from: http://www.gks.ru/ free_doc/new_site/finans/fin210g.

18. Export of Russia in 2015 [Internet]. Forex indicators. 2016. Date accessed: 4/03/ 2016: Available from: http://turtletable.com/article/export-russia-2015/. 
19. Bacher HU, Brulhart M. Progressive taxes and firm births. International Tax Public Finance. 2013 Feb; 20(1):129-68.

20. Kuzmin EA. Comparative analysis of budget efficiency of the functioning of enterprises and organizations of the industrial complex of a region (by the example of the Sverdlovsk Region). Financial analytics: science and experience. 2012 Oct; 38(128):40-53.

21. Cullen JB, Gordon RH. Taxes and entrepreneurial risktaking: theory and evidence for the United States of Journal and Public Economics. 2007 Aug; 91(7-8):1479-505.

22. Abdulgalimov AM. Optimization of taxation is a necessary condition for increasing the economic activity of organizations. Today and tomorrow of Russian economy. 2008; 19:51-6.

23. Gravelle JG. Reducing depreciation allowances to finance a lower corporate tax rate. Natonal Tax Journal. 2011 Dec; 64(4):1039-54.
24. Russia - GDP per capita. Trading economics: Date accessed: 2015: Available from: http://ru.tradingeconomics.com/ russia/gdp-per-capita.

25. The dynamics of corporate income tax in the consolidated budget of the region in 2015, in \% to 2014, by federal districts. Federal Tax Service of the Russian Federation. Date accessed: 2014: Available from: https://goo.gl/ceVl1q.

26. Akhmadeev RG, Kosov ME, Bykanova OA, Korotkova EM, Mamrukova OI. Assessment of the Tax Base of the Consolidated Group of Taxpayers in Russia using the Method of Polynomial Interpolation. Indian Journal of Science and Technology. 2016; 9(12):1-9.

27. Gulyaev PV. Characteristics of the Financial System of Resource Regions in Russia. Indian Journal of Science and Technology. 2016; 9(11):1-12. 